\title{
FLOODING SIMULATION AND CHANNELING IN THE VALLEY OF THE ANDES MOUNTAIN RANGE IN THE SOUTH OF PERU
}

\author{
ANDRES V. PEREZ ${ }^{1 *}$, NATALY PEREZ ${ }^{2} \&$ ANAI PEREZ $^{3}$ \\ ${ }^{1}$ National University of Saint Agustin, Civil Engineering Department, Peru \\ ${ }^{2}$ Duke University, Pratt School Engineering, USA \\ ${ }^{3}$ Columbia University, Graduate School of Architecture, Planning and Preservation, USA
}

\begin{abstract}
For this investigation, a maximum flow was generated with a hydrological simulation of extreme events in the southern zone of Peru of the Andes mountain range. The flow was reported to be $1,215.80 \mathrm{~m}^{3} / \mathrm{s}$ for the river Tambo. This flow was used to obtain the flood map of the valley. Subsequently, an earth dam has been designed to channel the flood. Finally, the flow of water was simulated again until the size and stability of the dam was adequate. The physiographic characteristics of the watershed were made with satellite geography and the GIS system. Probabilistic models and rainfall-runoff models were used for the frequency analysis. To simulate the flood, the two-dimensional differential equations of Saint-Venant were solved with the finite volume method; in order to do this, a net was made (networks), with the sizes of the cells being smaller than $5.0 \mathrm{~m}$ by $5.0 \mathrm{~m}$, resulting in a total of 70,455 cells. In the flood zone, a direct topographic survey was carried out, along with measurements of other field data.
\end{abstract}

Keywords: river, simulation flooding, earth dam.

\section{INTRODUCTION}

According to the National Meteorology and Hydrology Service, summer seasons in the Andes Mountains are characterized by very intense rainfall [1]. In recent years these intensities have increased due to the effects of climate change. Water flows from peaks of more than $6,000 \mathrm{~m}$ above sea level to low valleys full of agricultural land, located at $205 \mathrm{~m}$. above sea level, and generate floods in those valleys damaging agriculture and infrastructure.

The objective of this work was to simulate the flood for a maximum flow and for a set return period, design a dam to channel the simulated flood, and finally simulate the flow of water considering the proposed dam already built.

\section{METHODOLOGY AND MATERIALS}

\subsection{Location of the study area}

The study area is located in South America, specifically in the South of Peru in the department of Arequipa, in the sector of the Andes Mountain. Fig. 1 shows the high peaks of the mountain range to the shores of the Pacific Ocean.

\subsection{Hydrology}

As mention before, this zone is characterized by intense rains in the summer season, since it belongs to the high part of the Andes Mountain Range, where there are mountains with heights of more than 6000 meters above the sea. This zone is where rivers are born. As these

*ORCID: https://orcid.org/0000-0002-3404-4349 
rivers descend from the Andean mountain range, they converge to form higher order rivers. These higher order rivers cover several hundred kilometers and eventually flow into the Pacific Ocean.

\section{Drainage Network of the Tambo River Basin}



Figure 1: Location map of the study area.

The flood zone occurs in the lower part of the basin, starting at a $205 \mathrm{~m}$ elevation, where the river flow is large because the drainage basin is also large. The determination of the physiographic characteristics of the basin and its correct geographical location in UTM WGS84 coordinates was made with the satellite digital elevation system and later with the Geographic Information System (GIS).

The calculated values of the basin are area of the basin $\left(11838.58 \mathrm{~km}^{2}\right)$, perimeter of the basin $(1094.26 \mathrm{~km})$, length of the main channel of the river $(305 \mathrm{~km})$, starting point of the area of flood $205 \mathrm{~m} \mathrm{[2].}$

\subsubsection{Maximum design flow hygrogram}

After defining the physiographic characteristics of the basin, the hydrograph, which is fundamental data for the simulation, was determined. In order to calculate this hydrograph, 
the concept of the model of "maximum rainfall of 24 hours" was considered (this is the only data that is available). To do this the basin was divided into 105 sub-basins and a hydrological simulation procedure was carried out, as well as the rain frequency analysis and probabilistic models of extreme events for the calculation of the flow.

In the study basin, there is a regulation dam called Pasto Grande, which was considered to determine the hydrograph.

To determine this hydrograph, a percentage of risk of failure of the hydraulic structure (channeling dam) was considered; in this case the value is $20 \%$. Additionally, it was necessary to consider the expected life of the dike, in this case was 100 years, defined by Chow et al. [3]. A return period of 449 years was obtained, and this return period was used to determine the maximum flow which is reported to be $1,215.80 \mathrm{~m} 3 / \mathrm{s}$. The hydrograph is shown in Fig. 2.

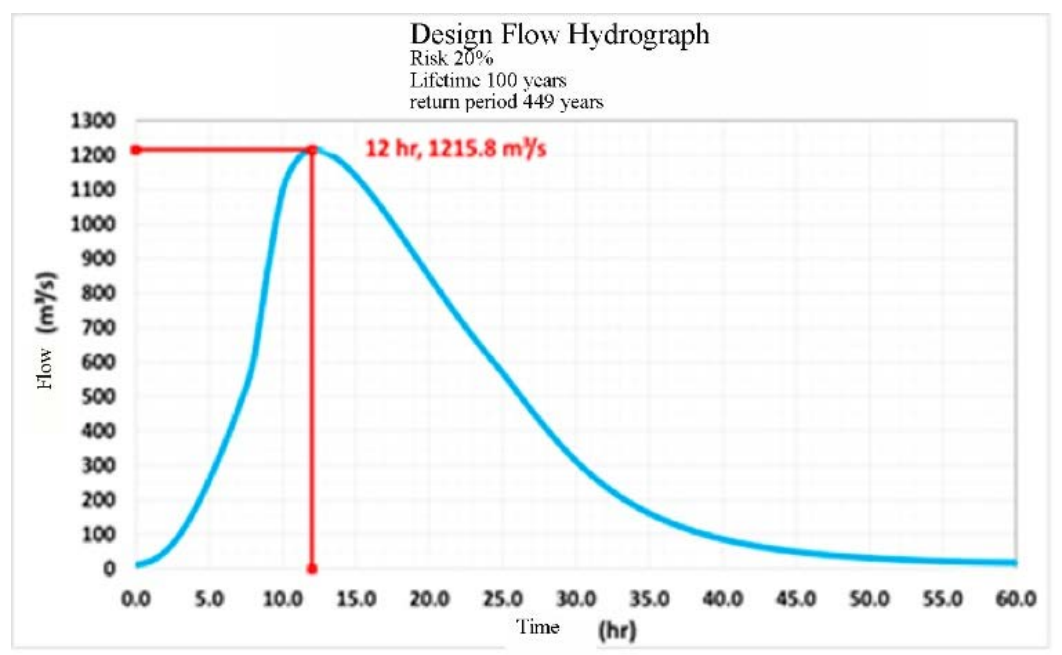

Figure 2: Hydrogram of maximum design flow is $1,215.80 \mathrm{~m}^{3} / \mathrm{s}$.

\subsection{Governing equations}

The basic equations that govern the flow of water on rivers are the equations of continuity and momentum of Saint-Venant two-dimensional defined in Chaudhry [4].

\subsubsection{Continuity equations}

The law of the conservation of mass of water flows is expressed using the equation of continuity as follows

$$
\frac{\partial H}{\partial t}+h \frac{\partial u}{\partial x}+h \frac{\partial v}{\partial y}+q=0
$$

where $H$ : elevation of the surface free of water; $h$ : water depth; $u$ : velocity on the "x" axis; $v$ : velocity on the " $\mathrm{x}$ " axis; $t$ : time; $q$ : infiltration in the riverbed.

\subsubsection{Equations of movement amount}

The second law of Newton for water flows can be expressed with the equations for the amount of movement in two-dimensional form; it is expressed for either the $\mathrm{x}$ or $\mathrm{y}$ axes. 
The equation of momentum in the $\mathrm{x}$-axis is as follows:

$$
\frac{\partial u}{\partial t}+u \frac{\partial u}{\partial x}+v \frac{\partial u}{\partial y}=-g \frac{\partial H}{\partial x}+v_{t}\left(\frac{\partial^{2} u}{\partial x^{2}}+\frac{\partial^{2} u}{\partial y^{2}}\right)-c_{f} u+f v .
$$

The equation of momentum in the y-axis is as follows:

$$
\frac{\partial v}{\partial t}+u \frac{\partial v}{\partial x}+v \frac{\partial v}{\partial y}=-g \frac{\partial H}{\partial y}+v_{t}\left(\frac{\partial^{2} v}{\partial x^{2}}+\frac{\partial^{2} v}{\partial y^{2}}\right)-c_{f} u+f u
$$

where $c_{f}$ : coefficient of background stress; $v_{t}$ : kinematic viscosity of water; $f$ : Coriolis coefficient. The two equations of movement amount consider: the viscous efforts of water, pressure, bottom resistance efforts, acceleration of gravity, as well as the effect of the rotation of the earth called the Coriolis effect. The bottom resistance effort is represented by the roughness coefficient of the channel of the river.

Eqns (1), (2) and (3) do not admit an analytical solution; consequently, these are solved with the finite volume method.

\subsection{Coefficient of roughness of the river channel and floodplain}

These roughness coefficients were taken directly from the river channel, considering the concepts of roughness proposed by Manning and defined by Chow [5], and taking into account: roughness of the bottom of the channel, resistance to flow due to vegetation, degree of sinuosity of the channel, irregularities of the channel, existing obstructions in the channel, etc. The concept proposed by Cowan was followed and the results can be seen in the map shown in Fig. 3. This data map is essential for the simulation.

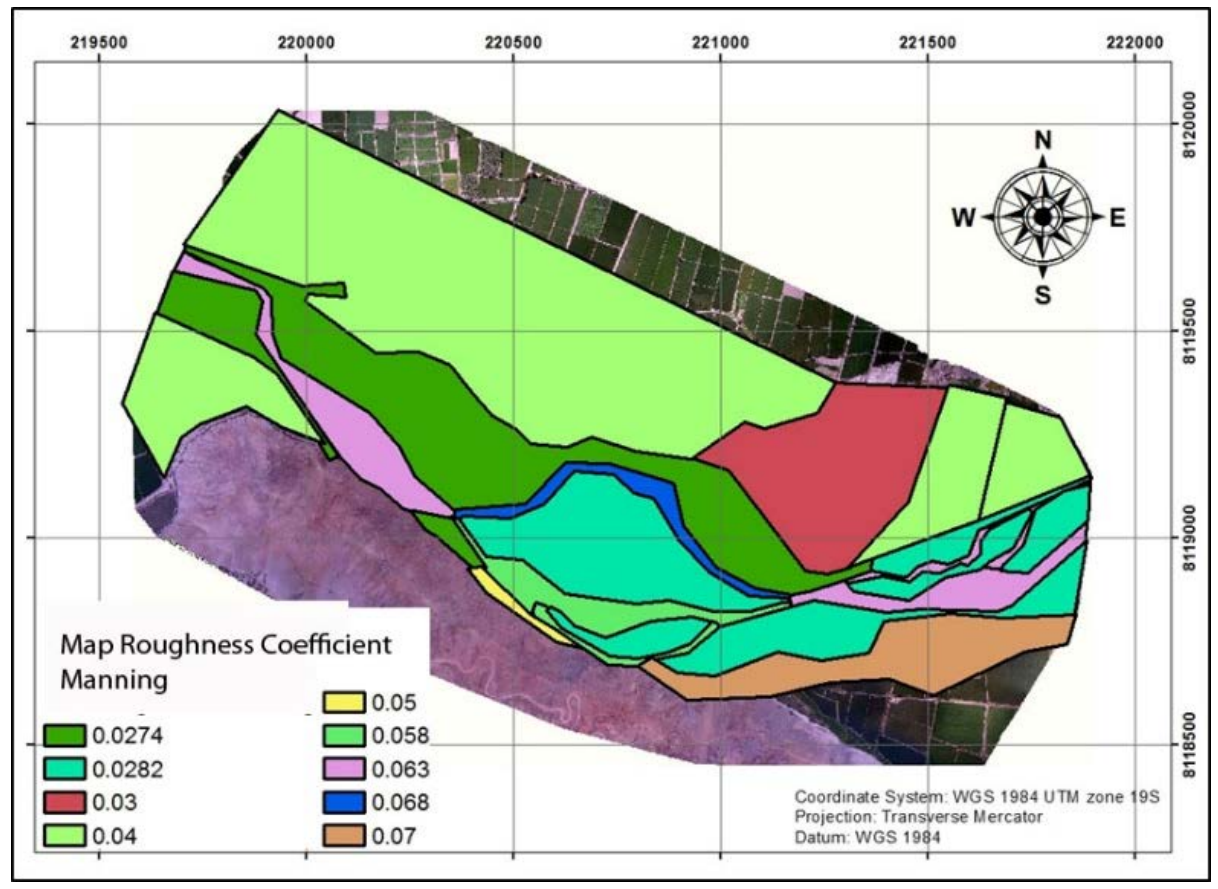

Figure 3: Manning roughness coefficient for the flood zone of the Tambo River, Arequipa, Peru. 


\section{RESULTS}

\subsection{Flood simulation of the plain}

This simulation was carried out with specialized software that uses the finite volume method to solve eqns (1), (2), (3) (Chung [6], Anderson [7], Perez and Perez [8]) with border and initial conditions that where measured at the field. The computational step time in the flow modeling for two dimensions was based on the Courant number-Hec [9]. First, the digital terrain model was generated with a direct topographic field survey in UTM-WGS84 coordinates. Next, the Manning roughness coefficient map was considered for the river channel and the flood plains. Then the geometry or domain of the model was generated in structured nettings with the following characteristics: the netting dimensions $\Delta x=5 \mathrm{~m}$ and $\Delta y=5 \mathrm{~m}$; the number of nettings/cells generated is 70.455 ; and the computational time step of $\Delta t, 2$ seconds. With these values, the conditions of the Courant number were met. Finally, the boundary and initial conditions were introduced, being the hydrograph upstream and the slope downstream. For the calibration process, a suitable section where the values of the hydraulic variables are as uniform as possible was chosen. The simulated values were compared with the values obtained with other methods until these values are similar. The results of the maps are shown in Fig. 4 and Fig. 5.

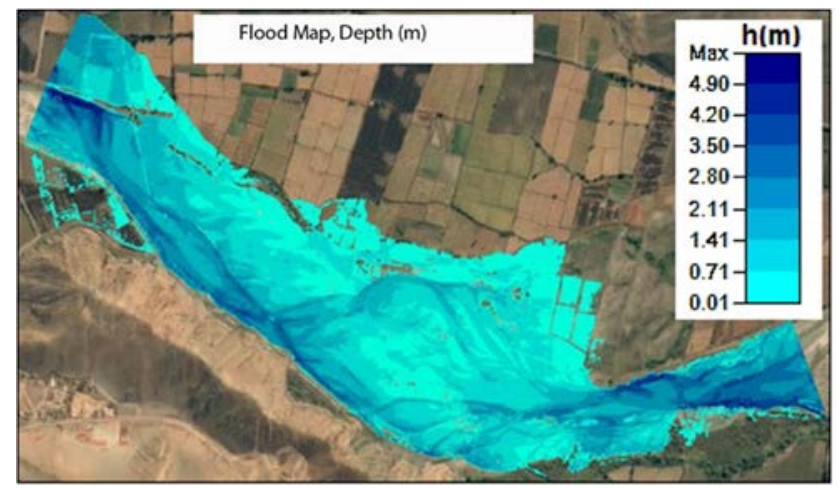

Figure 4: Depth result (m) of flood simulation for the maximum flow of 1,215.80 $\mathrm{m}^{3} / \mathrm{s}$.

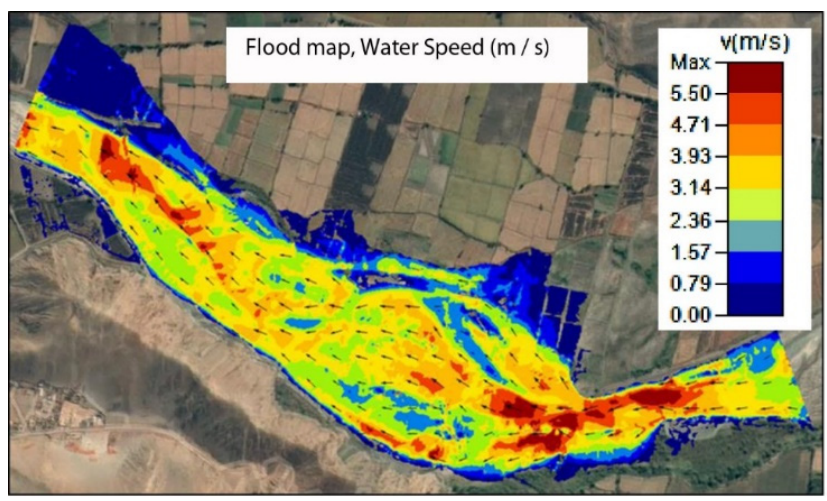

Figure 5: Velocity result $(\mathrm{m} / \mathrm{s})$ of flood simulation for the maximum flow of $1,215.8 \mathrm{~m}^{3} / \mathrm{s}$. 


\subsection{Design of the earth dam to channel the flow}

In order to protect the floodplains of this valley from flooding, an earth dam was designed along the Tambo. To do this, the calculated design flow was used so that other hydraulic variables were determined, such as the depth of flow, speed in both directions, erosion and sedimentation. The stability of the dam was analyzed (Perez [10]). A representation of the dam is shown in Fig. 6.

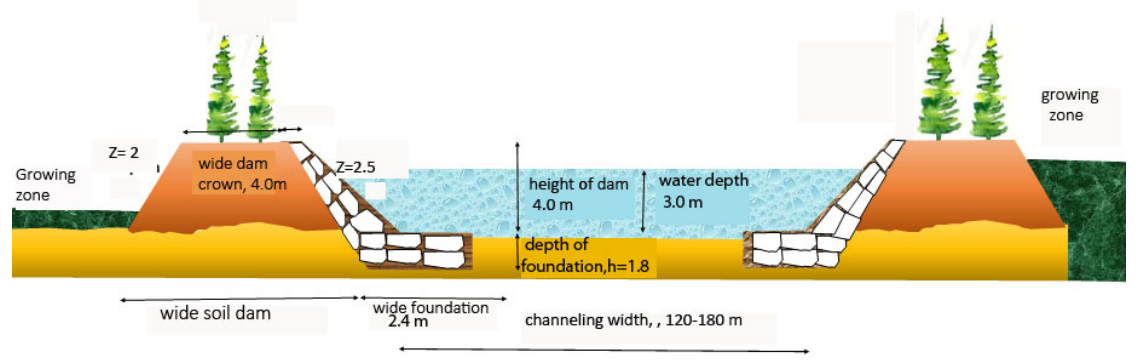

Figure 6: Diagram of cross section of channeling with earth dam.

Due to topographic conditions of the area like dam stability, erosion, etc., the dike height presents a value around $4 \mathrm{~m}$, agreeing with values from previous simulations. Moreover, the width of the crown was set at $4 \mathrm{~m}$ with slopes of $1 \mathrm{~m}$ in vertical and $2 \mathrm{~m}$ in horizontal. Those values were established based on the material presented at the area and the stability of the dam. The general scour was determined with hydrodynamic simulation and compared with empirical methods (Graf [11]).

\subsection{Simulation results with the proposed dam}

After the proposed dimensions of the dam were implemented and the dam was designed with these improvements, the simulation was run again using the maximum flow reported above. Floods no longer occur in the agricultural lands and the dam does not collapse; Figs 7 and 8 show the results.

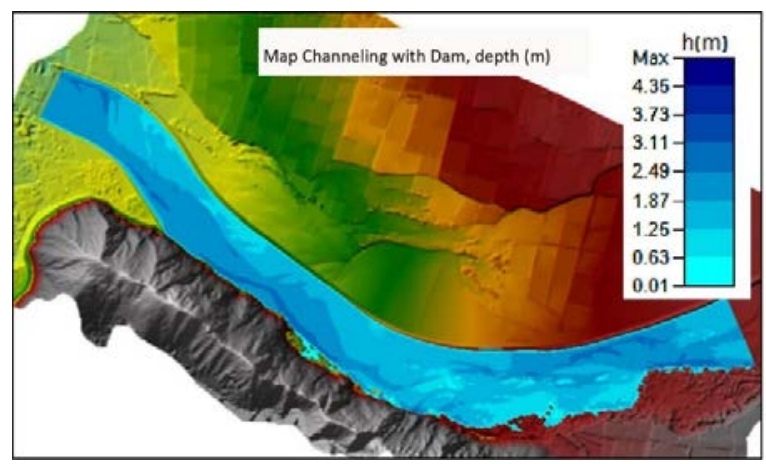

Figure 7: Result of simulation depth (m) after channeling, for a flow of $1215.80 \mathrm{~m}^{3} / \mathrm{s}$. 


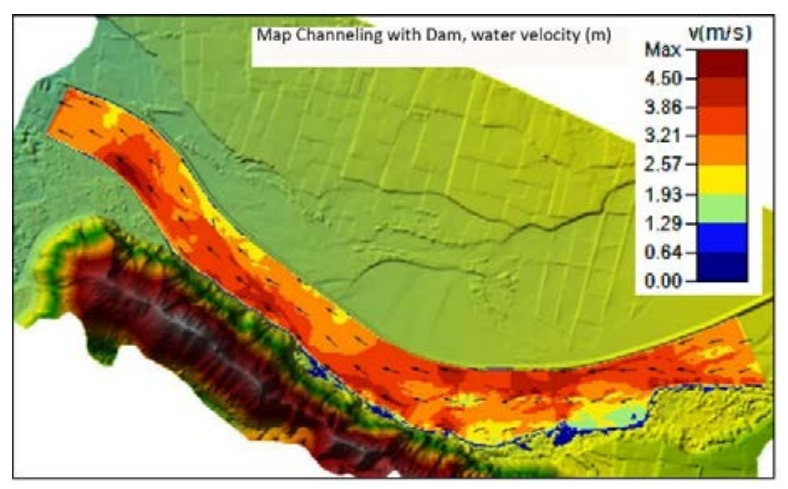

Figure 8: Simulation result of flow velocity $(\mathrm{m} / \mathrm{s})$ for flow $1,215.80 \mathrm{~m}^{3} / \mathrm{s}$ after channeling.

\section{CONCLUSIONS}

The variations of rainfall intensities in the Andes Mountains in southern Peru are great, with rainfall records of more than $50 \mathrm{~mm}$ during 24 hours in the high peak areas, and rainfalls of $0 \mathrm{~mm}$ for a 24 hours range in the lower parts. When conducting the frequency analysis study, rainfall is much greater. The lower part of the watershed near the Pacific Ocean is arid; therefore, irrigation with upstream water is necessary. Hydrological and hydraulic simulations in the Andes Mountain range are challenging due to the lack of records of river flows. There are only limited rainfall records. Currently, a research for an area with extreme rains is being carried out in the Andean mountain range of Peru.

\section{REFERENCES}

[1] Datos meteorológicos, Lima, Perú, Servicio Nacional de Meteorología e Hidrología (SENAMHI). https://web2.senamhi.gob.pe/?p=descarga-datos-hidrometeorologicos. Accessed on:12 Jun. 2017.

[2] Perez, A.V., Quispe, F. \& Valeriano, Hydraulic and hydrological modeling. Thesis for professional degree, National University Saint Agustin: Arequipa, 2017.

[3] Chow, V.T., Maidment, D. \& Mays, L., Hydrologic Applied, McGraw-Hill: New York, pp. 417-421, 1988.

[4] Chaudhry, M., Open-Channel Flow, Prentice Hall: Englewood Cliffs, pp. 346-354, 2008.

[5] Chow, V.T., Open Channel Hydraulics, McGraw-Hill: New York, pp. 101-125, 1994.

[6] Chung, J.T., Computational Fluid Dynamics, Cambridge University Press, pp. 218227, 2002.

[7] Anderson, J., Computational Fluid Dynamics: The Basics with Applications, McGrawHill: New York, pp. 145-156, 1995.

[8] Perez, A.V. \& Perez, N., Simulation with the finite element method of air pollution carbon monoxide in the City of Arequipa (Peru). WIT Transactions on Ecology and the Environmental, vol. 207, WIT Press: Southampton and Boston, pp. 22-33, 2016.

[9] Hydrologic Engineering Center (HEC). Washington, DC, 20314-21000. www.hec.usace.army.mil/software/hec-ras/. Accessed on: 15 Dec. 2017.

[10] Perez, A., Design Hydraulic Structure, National University Saint Agustin: Arequipa, 2016.

[11] Graf, W.H., Hydraulics of Sediment Transport, McGraw-Hill: New York, pp. 121145, 1989. 